\title{
Promoting Leadership in the Ongoing Professional Development of Teachers: Responding to Globalization and Inclusion
}

\author{
D. F. Philpott \\ E. Furey \\ S. C. Penney \\ Memorial University of Newfoundland
}

\begin{abstract}
This paper explores the need for innovative leadership in teacher education in the Canadian context, with a particular call for renewed professional development of current teachers. Within a country defined as multicultural, recent demographic shifts, interregional migration, growing ethnic diversity, and the emergence of a paradigm of inclusion, contemporary classrooms are evolving at a pace faster than projected. While inclusive education emerged from the growth of services for children with disabilities, it is now a concept much broader than initially conceived. Expanded concepts of learner differences are necessitating an urgent need for leadership in redeveloping effective training for current teachers. This paper argues that ongoing professional development must be characterized by six focus areas in order to empower teachers with pragmatic skills to balance the needs of their diverse classes. The authors conclude that a first step in this process is training for administrators who lead professional development in schools.
\end{abstract}

Concern for the readiness of new teachers to face the challenges of contemporary classrooms has been the source of much research, debate, and criticism. Despite the fact that classroom teachers are assuming more responsibility in meeting the needs of all students, many of them do not feel prepared to instruct students of diverse cultural backgrounds or abilities (Ellins \& Porter, 2005; Forlin \& Hopewell, 2006; Jenkins \& Ornelles, 2009). In a recent Canadian study, Crocker and Dibbon (2008) reported that while $81 \%$ of Canadian school principals ranked pre-service training in accommodating diverse needs as important for new teachers, only $8 \%$ felt that current graduates are prepared. This finding echoes numerous provincial reviews, such as Alberta's call for improving pre-service teacher education programs and expanding post-service training to ensure competent teachers who are ready to face the demands of diverse classrooms (Government of Alberta, 2006). Newfoundland and Labrador (Philpott, 2007) concluded that $87.4 \%$ of teachers 
report little or no training in the area of diversity. Similar findings have emerged in Nova Scotia (Government of Nova Scotia, 2007) and Ontario (Ontario College of Teachers, 2006) and have led to calls for reform of initial teacher training. This concern is hardly unique to Canada. Globally, a growing body of literature is voicing similar concerns for teacher readiness to meet the needs of students with exceptionalities as well as those who are culturally/linguistically diverse (e.g., Brown, Higgins, Pierce, Hong, \& Thomas, 2004; Buysse, Goldman, \& Skinner, 2003; Klinger, Vaughn, Schumm, Cohen, \& Forgan, 1998; Lyon, 2005; Stanovich \& Jordan, 2000; Taylor \& Whittaker, 2009; Waldron \& McLesky, 1998; Wiener, 2004; Zigmond \& Baker, 1995). Levin (2009) recognized this call to reform initial teacher training programs, but questioned its effectiveness in reforming education or in supporting existing teachers. He concluded that staff turnover rates are too slow to effect systemic change and that "new teachers do not change schools; schools change new teachers" (para. 3); that is, newly trained, novice teachers become indoctrinated into the practice and culture of existing schools. He actually called for more effective leadership in ongoing post-service training which partners with parents and engages students. While Levin did not negate the importance of initial teacher preparation, he emphasized the need for renewed focus on post-service training so as to ensure competency of existing teachers.

This shift in thinking toward effecting change by focusing on innovative leadership in training current teachers might be timely in the Canadian context, given how quickly change is occurring. Today's retiring teachers who started the profession in the late 1970s began their careers before computers entered our classrooms, when special education, if it existed at all, was relegated to an isolated room in a far corner of the building; and before the Canadian Charter of Rights and Freedoms would help redefine the fabric of Canadian society. Initial training programs would have been hard pressed to imagine the potpourri of issues which those teachers would face as their careers wound to a close or the plethora of curriculum and organizational changes that they would encounter emanating from the school reform movement (National Commission of Educational Excellence, 1983). Likewise, few expect today's teacher training institutions to predict, much less ready candidates for, the depth of change that these new educators will encounter. Such realizations force consideration that teacher training is as much a process of providing effective training throughout their careers as it is about initial training programs. Such consideration is underscored by the rate at which contemporary classrooms are being redefined. School administrators play a critical role as facilitators of pre- and post-service professional development to meet the needs of contemporary classrooms.

\section{Contemporary Classrooms}

While both globalization and inclusion might well be entrenched concepts in today's classrooms, practising teachers might not have even heard of the concepts in their initial training programs, much less been instilled with strategies to respond effectively to diverse student needs. The United Nations (United Nations Development Programme, 2009) reported that "We live in a highly mobile world, where migration is not only inevitable but also an important dimension of human development. Nearly one billion, which is to say one out of seven, people are migrants" (para. 1). This trend had been predicted for some time but is proceeding faster than expected due to such factors as economic disparity and a search for employment (Gould \& Finlay, 1994); internal and international conflicts; human rights concerns; ineffective and collapsing governments; absence of personal security; rise of multi-national corporations; globalized media; 
and improved travel (Taylor \& Whittaker, 2009). Sassen (1996) suggested that many countries are supporting immigration growth as a means to meet labour demands, and international initiatives, such as the 1975 Helsinki Accord, the 1980 Refugee Act, and the 1990 International Convention on Protecting the Rights of Migrant Workers and their Families, are all easing restrictions on family migration. Taylor and Whittaker (2009) added that the 1999 Programme of Action on Population and Development has further encouraged countries to cooperate on immigration policy by focusing on the rights of the person.

While increased immigration is changing communities around the world, in Canada, with its multicultural nature and reliance on immigration to fulfil labour demands, the resultant diversity is pronounced, especially in our classrooms. The 2006 census (Statistics Canada, 2007, 2008a) determined that there are over 200 languages spoken in Canadian schools, and $20 \%$ of the population reports a first language other than English. The population is shifting radically towards greater cultural diversity and it is predicted that by $201723 \%$ of Canada's population will be from a visible minority with at least two thirds of that diversity stemming from new immigration (Statistics Canada, 2008b).

These shifts are already being seen in classrooms in large urban settings, with teachers witnessing a whole new level of challenge in accommodating learner diversity. The vast majority of new immigrants tend to settle in urban areas, resulting in growing diversity of inner city schools as noted, for example, in Toronto, Vancouver, and Montreal. Recent census data identified that one in two people in the city of Toronto are foreign-born (Statistics Canada, 2008b). In one school district alone, 75 different languages are spoken and only $53 \%$ of students have English as their first language (Toronto District School Board, 2009). Likewise, in Richmond, British Columbia, three out of five people are foreign-born (Statistics Canada, 2008b), only 43\% of students are English-speaking, and in excess of 126 different languages are spoken in their schools (Richmond School Board, 2010). In Montreal, where one in three is foreign-born (Statistics Canada, 2008b), one school district reported a student population that represents more than 130 different cultures (English Montreal School Board, 2010). These three cities alone attract $69 \%$ of new immigrants who generally move toward the more urban areas (Statistics Canada, 2008b). Adding an even greater complexity to this ethnic diversity is a $33 \%$ rise - more than five times the national average - in intercultural or mixed unions, resulting in multicultural and multilinguistic families (Statistics Canada, 2008b).

Cultural diversity is not just an urban issue, but a rural one as well, given Canada's mushrooming Aboriginal population. The 2006 Canadian Census reported an Aboriginal population of nearly 1.2 million, with a projected growth rate of $34 \%$ in the next 20 years. Of greater concern to educators is the age of this population, with $48 \%$ of the Aboriginal population being schoolaged (Statistics Canada, 2007, 2008a). Primary responsibility for educating the Aboriginal population rests with the federal department of Indian and Northern Affairs (INAC), which, in the 2007-2008 school year, operated 515 schools, having a student population of 109,000 and a budget of 1.2 billion dollars. While $60 \%$ of those students were enrolled in reserve-based, bandrun schools, a growing population of youth are enrolling in provincial schools (INAC, personal communication, October, 2008). Complicating service delivery for this diverse population is a pronounced increase in interregional migration and a population shift from rural to urban regions. Economic and labour market demands are resulting in families moving between provinces at an increasing pace (Statistics Canada, 2008b).

As globalization continues to change demographics of countries - and the mobility of citizens within countries - it is redefining the profession of teaching, particularly the process of 
responding to diverse needs. McCarthy, Rezai-Rashti, and Teasley (2009) argued that such globalization trends are changing the very identity of schools:

Today's dominant form of globalization is throwing new system-based identity crises onto schools, as educators are confronted with the proliferation of difference and multiplicity. New, complex forms of identity and affiliation are not only defining the lives and lifestyles of immigrant youth outside of schools, but are powerfully impacting their in-school experiences as well. (p. 77)

Taylor and Whittaker (2009) discussed the resultant implication on teacher training programs:

The implications for teachers are obvious. Even in areas of the country that remain predominantly White, it is essential that teachers learn about the cultures and languages of many children who are arriving in greater numbers and entering their schools for the first time. Furthermore, many of the jobs available in the next decade will be in urban areas where the population is likely to be even more diverse. All children will need to work and live harmoniously with members of many diverse groups. Teachers will need to develop the knowledge, skills, and attitudes necessary to prepare a diverse population of students for success in the mainstream, while also respecting their cultures and languages of origin. (p. 11)

While cultural diversity is a relatively new challenge for teachers, the global shift toward inclusive education has been taxing their readiness for some time. Emerging from evolving social norms of disability, and paralleling the evolution of human rights and civil liberties, contemporary educational services for children with disabilities have evolved from segregated settings to environments of inclusivity (Kauffman, 1981). This paradigm of inclusion has been supported by The School Reform movement of the 1980s which called for tighter accountability measures and a more explicit curriculum to replace the traditional parallel stream of special education with a blended, universal quality model of education for all students (Kauffman, 2000; Lipsky \& Gartner, 1997; Salend, 2001; Thoma, Bartholomew, \& Scott, 2009). Furthering the call for quality education for all students was the mounting criticism of traditional diagnostic/prescriptive models of special education, widely seen as being ineffective, lacking theory, and marginalizing to individuals (Fuchs \& Fuchs, 1995; Hockenbury, Kauffman, \& Hallahan, 2000; Skrtic, 1995). Additionally, support for this reconceptualised, inclusive system of educational services for children with exceptionalities has been supported by the United Nations declaration of the Rights of Disabled Persons in 1975, the International Year of the Disabled (1981), and UNESCO's 1994 world conference on special education with its call for greater inclusive practices (Abosi, 2001).

This paradigm of inclusive education actually bridges the response to students who have individual needs because of ability with those who have cultural or linguistic needs. Inclusion is viewed as a concept which is central to a democratic school system, one espousing a philosophy of community development and educational programs that create environments embracing all differences (Sands, Kozleski, \& French, 2001; Smith, 1998; Stainback \& Stainback, 1992; Thomas, 1997). It is a philosophy of education which focuses on diverse teaching strategies which meet diverse needs by empowering the classroom teacher with the knowledge, skills, and willingness to welcome all students. An inclusive approach to education is effective for students of differing abilities and differing cultures. Banks et al. (2005) commented on the appropriateness of a paradigm of inclusion to meet the needs of both groups:

The ideas of culturally responsive classrooms and inclusive classrooms are not entirely the same, but they are similar. Specifically, both terms suggest that schools and teachers need to develop 
classrooms that are supportive of children and accepting of difference. Within both of these conceptions, children's strengths are emphasized and differences are considered a positive part of a learning environment because they allow children to share and experience diverse perspectives. ( $p$. 255)

Today, inclusive education is the global paradigm of care, where the classroom teacher is seen as the primary support person for all students and where "good teaching" is characterized by an increasingly broad skill set. However, the implications of inclusion eclipse the implications of globalization and underscore the urgency of administrators to affect enhanced ongoing postservice opportunities. While ethnically diverse students tend to be more prevalent in either inner city or Aboriginal communities, all teachers, in all schools, will be challenged to meet the needs of exceptional learners. Hutchinson (2009) stated emphatically that "inclusive education is an issue within the context of Canadian society, not just within the context of Canadian schools.... In Canada, if we choose to teach, we are choosing to teach in inclusive settings" (p. xxv). Hutchinson's suggestions of an attitude toward inclusiveness are both timely and wise. School administrators recognize the importance of training teachers to face such complexities and of developing positive attitudes to accommodate all learners, regardless of why they might differ from the perceived norm (Foster, 2004; Loreman, 2007).

\section{Teacher Attitudes}

Central to change, certainly to acquiring a broader skill set to respond to diversity, is teacher attitude. Teachers who feel unprepared to meet diverse needs of students suffer diminishing confidence in their own knowledge and skills (Eggan \& Kauchak, 2006; Poulou, 2007). Teacher attitudes towards inclusive practice are critical to successful inclusion and impact classroom practices and ultimately student achievement (Loreman, 2007; Poulou, 2007; Stanovich \& Jordan, 2002). Attitudes are linked to the types of activities planned and the structures put into place in a classroom environment. Loreman (2007) explained, "Where teachers want to involve all learners, they generally tend to devise activities which support that goal" (p. 24). Attitudes also impact teachers' interactions with their students. Jordan and Stanovich (2001) found teachers' beliefs to have a major influence in shaping their views of their students and what and how they were taught. These researchers reported that teachers who saw barriers to learning as being environmental were more likely to engage children than were teachers who saw the barriers to learning as being inherent to the children. Such teachers who view the obstacle as internal believe that exceptional or at-risk students "were unable to keep up with the rest of the class, and that other, more specialized teachers should be primarily responsible for instruction" (p. 45). This attitude places the responsibility for students with disabilities firmly upon the special education or specialist teacher, resulting in the classroom teacher's limited responsibility for programming and limited interaction with the student. Murphy (1996) recognized this belief by reporting that once negative attitudes of teachers toward inclusion are established they can be difficult to change. Moreover, they result in teachers having lower expectations for their students and subsequent lower achievement levels (Loreman, 2007).

Wiener (2009) noted that the way a teacher interacts with, and the attitudes demonstrated towards, children with disabilities can impact his or her acceptance within the inclusive classroom: 
Teachers who view these students as a challenge rather than a burden, who believe that they are able to impact the students' peer relationships, and who implement evidence based strategies to prevent peer victimization, enhance social status, and lead to the formation of meaningful friendships, will help students with learning disabilities become fully included in the general education classroom. (p. 20)

While teacher attitudes and beliefs play a critical role in the micro climate of the classroom and impact student achievement, the macro climate of the whole school is of critical importance. If diversity is an expanded concept in today's schools and if such trends are going to expand, it falls to current school leaders to respond effectively and ensure healthy and responsive environments. School leadership has long been seen as central to establishing this healthy school environment of positive attitudes toward diversity, facilitated by the principal, but shared by the entire teaching team (Foster, 2004; Loreman, 2007; Stanovich \& Jordan, 1998). Perhaps at no point in our history has the need for effective leadership to embrace and accommodate differences been more urgent. As society redefines itself in pluralistic concepts and embraces a much broader interpretation of inclusiveness, school leaders must work as diligently at leading this process as teachers must in enacting it in their classrooms. New approaches to teaching, new articulations of instruction, and new concepts of the community school must be as pragmatic as they are effective.

\section{Six Core Areas for Renewed Professional Development}

In preparing for this broader and more positive concept of diversity and increased effectiveness of training, those entrusted with providing professional development for educators (administrators as well as teachers) must undertake a multitude of responsibilities. Critical areas of responsibility include developing and implementing policies to support inclusion, creating awareness of culture and disability, nurturing positive attitudes toward inclusion, and encouraging professional development for evidence-based teaching strategies that are collaborative and meaningful. Each of these is discussed separately.

\section{Professional Development for Inclusive Policy}

Central to encouraging higher skill acquisition to respond to greater diversity is the articulation of clear policies to support and guide it. Loreman (2007) cautioned that "even supportive leaders will have difficulty promoting inclusive education in an environment devoid of supportive policies" (p. 25). However, Naylor (2005), in a pan-Canadian review of policy, reported that "no Canadian province has a fully inclusionary system of education" (p. 7). In fact, even a cursory review of the policies across Canada indicates that while the concepts of equity and inclusion are a part of policy documents, variations exist in the model of inclusion and in its implementation. Inclusion within the Canadian context is not synonymous with children being placed within the regular classroom for all their instructional needs. While there may be overarching provincial policies, an examination of individual school board policies indicated evidence of a continuum of placements, including alternative schools (Hutchinson, 2009; Philpott, 2007).

However, policies and legislation do not necessarily ensure that changes will actually occur. There is a need for sustained investment by stakeholders-those implementing change - to prevent policies being ignored in favour of the status quo: 
Large scale, sustained improvement in student outcomes requires a sustained effort to change school and classroom practices, not just structures such as governance and accountability. The heart of improvement lies in changing teaching and learning practices... and this requires focused and sustained effort by all parts of the educational system and its partners. (Levin \& Fullan, 2008, p. 291)

Lloyd (2008) recognized that implementing policies on inclusion is an extremely difficult task. She reported that the various policies which schools are expected to implement are in opposition to the structures that are set out in our society. For example, she suggested that comparisons of children and schools on standardized measures of achievement, and expectations for children to eventually make an economic contribution, prevent implementation of a model of full inclusion. In this model, provision of remedial strategies to students who do not meet the comparative standard, with the intent of producing a cohesive society, inherently devalues diversity. Thomas and Loxley (2007) echoed these sentiments: "[t]here is an inconsistency between diversity and the positive conception of difference and an imperative to promote national economic well-being" (p. 65). Administrators support schools in creating inclusive school environments by helping teachers perceive children's difficulties not only within the context of the school but within the wider context of our society.

Goddard and Hart (2007) indicted that board and school policies are key to supporting principals in developing inclusive schools for all children. Policies support monitoring and provision of resources to enable inclusive practices and equal and equitable access to language programs, early literacy, and culturally balanced curriculum. As well, policies enable schools to actively recruit, hire, and retain teachers from minority cultures.

\section{Professional Development for Diversity}

Most existing educators, as well as students currently enrolled in teacher-training programs, are from white, middle to upper-middle class backgrounds, and may not recognize how their practice is influenced by their own cultural values (Goddard \& Hart, 2007; Hastie, Martin, $\&$ Buchannan, 2006). A teacher's mere understanding of diversity, awareness of the nuances of culture, selection of planned lessons, activities, classroom structure, and methods of both praise and discipline are especially influenced by his or her own cultural background. Subsequently, professional development needs to support teachers in a personal examination of their awareness of the very nature of difference. Before appropriate strategies can be acquired new attitudes and broader understandings might well have to be fostered. Certainly self-examination will have to be initiated.

Weinstein, Tomlinson-Clarke, and Curran (2004) reported that a teacher's lack of understanding about cultural differences can create conflict within the classroom. Similarly, insufficient understanding about differences can hinder meaningful access to the curriculum. While, in recent years, teachers have increased their awareness that students with disabilities learn differently and require varied ways to participate in the mainstream education curriculum, many teachers lack knowledge of exceptionalities necessary for more successful inclusion of students (Jenkins \& Ornelles, 2009). Pre-service and practising classroom teachers have identified their own inadequate knowledge and understanding of children with learning difficulties (Jenkins \& Ornelles, 2009; Kamens, Loprete, \& Slostad, 2003). Jenkins and Ornelles (2009) noted that less than $50 \%$ of classroom teachers felt knowledgeable about the capabilities of students with disabilities. If such findings continue to call for professional development in 
accommodating students with disabilities who have been included in regular classrooms for some years, one can only imagine the training required for teachers in understanding the needs of culturally diverse students. Those charged with leading this process must understand the importance of classroom teachers being informed about differing abilities and cultures to enable more effective instructional aligning and student-specific accommodations, as well as prevent stereotypes and discrimination (Golder, Jones, \& Quinn, 2009).

As is the case with accommodating students with disabilities, much of the literature surrounding accommodating students from culturally diverse backgrounds stresses the importance of teacher relationships with students and the wider community, including the child's family (Goddard \& Hart, 2007; Wilgosh \& Scorgie, 2006). It is also important that school leaders have an understanding of the principles of exceptionality and cultural diversity. Goddard and Hart (2007) concluded that while many principals follow board policies they "...use avoidance strategies to minimize differences with the intention of creating equitable access and opportunity for all students. The lack of attention to differences, however, can create situations where only students who adjust to the dominant culture will succeed" (p. 17). They go on to caution that

...through the implementation of policies and procedures that view all children as culturally, linguistically and ethnically the same, the nuance of the individual learning style is lost. The leadership of a principal in a multicultural society requires strategies of inclusion to create a culture of equitable access for all children. (p. 16)

\section{Professional Development to Nurture Positive Attitudes}

Teacher awareness of differences must be balanced with an attitude that acceptance of such diversity is within both their developing skill set as well as their professional responsibility. While ongoing skill acquisition is a post-service concern, Sharma, Forlin, Loreman, and Earle (2006) identified establishing positive attitudes as an issue for pre-service training. Silverman (2007) examined attitudes of pre-service teachers towards inclusion and noted the importance of teacher educators promoting and fostering the inclusive model and having the necessary skills to implement such models. Silverman further indicated that a positive attitude toward inclusion and a belief that learning ability is improvable are essential for all teachers of students with disabilities in inclusive environments. Stanovich and Jordan (2002) identified "a sense of teaching efficacy" and "a repertoire of teaching behaviours" (p. 175) as being key characteristics of teachers in the successful inclusive school. Moreover, the responsibility for establishing this sense of efficacy and repertoire of behaviours is identified as being shared between those engaged in delivering pre-service training to teachers and current school leaders (Munby, Russell, \& Martin, 2001). School principals, as well as post-secondary educators, strengthen teachers' confidence by recognizing the "authority of experience" of all teachers (Burbules \& Bruce, 2001, p. 1113). While the role of administrators in nurturing positive attitudes and beliefs is essential for inclusive classrooms, incorporation of effective evidence-based teaching strategies is mandatory in professional development.

\section{Professional Development for Evidence-based Teaching Strategies}

While the teaching profession requires a healthy understanding of diverse strategies in general, most classroom teachers tend to struggle with specialized or robust teaching practices 
when asked to individualize instruction and assessment (Jenkins \& Ornelles, 2009; Leko \& Brownell, 2009; Wedell, 2005). Jenkins and Ornelles (2009) reported that less than 50\% of classroom teachers actually felt knowledgeable about or prepared to use assistive technology to facilitate learning or communication. Similarly, Leko and Brownell (2009) identified that an identical number of special education teachers felt informed about differentiating instruction. Research indicates minimal preparation in both pre- and post-service training models for regular and specialist teachers in differentiating instruction and individualizing supports, especially in content areas for students with specific needs (Golder et al., 2009; Leko \& Brownell, 2009; Norwich \& Lewis, 2001). Classroom teachers are also seeking strategies on accommodating students with behavioural, emotional, and social difficulties (Buell, Hallam, Gamel-Mccormick, \& Scheer, 1999; Cook, Tankersley, Cook, \& Landrum, 2001; Jenkins \& Ornelles, 2009).

Such limited knowledge necessitates a need for innovation in establishing professional development on both acquiring and using teaching strategies for instructional differentiation (Griffin, Jitendra, \& League, 2009; Jenkins \& Ornelles, 2009). In an effective inclusive school, classroom teachers are supported in understanding student abilities, in assuming greater responsibility, and in integrating effective strategies for both instruction and evaluation (Emanuelsson, 2001; Golder et al., 2009; Jenkins \& Ornelles, 2009; Kamens et al., 2003; Lohrmann, Boggs, \& Bambara, 2006). Likewise, in an effective inclusive school, leaders prioritize establishing professional development to respond to needs of teachers by promoting in-depth, empirically-validated teaching strategies for specific curricular areas, as well as social/emotional needs (Baker \& Martin, 2008; Forlin \& Hopewell, 2006; Leko \& Brownell, 2009; Ross \& Blanton, 2004).

\section{Professional Development for Collaborative Teaching}

In order to support children of diverse cultural backgrounds and abilities, school leaders need to ensure opportunities for effective professional development which supports collaborative teaching. However, opportunities for collaboration are often lacking for pre-service and postservice teachers. Despite the apparent awareness by postsecondary institutions of the importance of providing structured training in collaboration, beginning teachers have identified inadequate training in this area as a major limitation (Kamens, 2007; McKenzie, 2009; Otis-Wilborn, Winn, Griffin, \& Kilgore, 2005; Scruggs, Mastropieri, \& McDuffie, 2007). Only 53\% of special education teachers and $29 \%$ of general education teachers received collaborative content during their pre-service preparation training (Carlson, Chen, \& Schroll, 2002; Griffin et al., 2009). While special education pre-service teachers are substantially more prepared to collaborate than preservice classroom teachers, their collaborative relationships are often disjointed or nonexistent (McKenzie, 2009). In addition, practising classroom and special education teachers often do not experience meaningful collaboration in inclusive classrooms (Fennick \& Liddy, 2001; Mastropieri, Scruggs, \& Graetz, 2005; McKenzie, 2009; Scruggs et al., 2007).

Effective school leaders enable their schools to become professional learning communities of practice and knowledge-building to assist their teachers in addressing needs of students of differing abilities and cultures. Through collaborative communities of inquiry, classroom and special education teachers are encouraged to question critically and "make visible" their tentative and "taken for granted" assumptions and beliefs about teaching and learning for all students (Cochran-Smith \& Lytle, 1999, p. 293; also see Bakken, Clark, \& Thompson, 1998; Ross \& Blanton, 2004). Reflective, inquiry-based discussions among teachers encourage them to engage in collaborative problem-solving to identify and address ways of improving their instruction for 
students of diverse cultural backgrounds and abilities, to clarify collaborative roles and responsibilities, and to identify common concerns hindering collaborative pedagogy (Baker \& Smith, 2001; Billingsley, 2003; Brownell, Adams, Sindelar, Waldron, \& Banhover, 2006; Griffin et al., 2009; Hobbs \& Westling, 2002; Jenkins \& Ornelles, 2009; Kamens, 2007; Laferriere, Erickson, \& Breuleux, 2007; Leko \& Brownell, 2009; Lohrmann et al., 2006; Loucks-Horsley, Love, Stiles, Mundry, \& Hewson, 2003; McKenzie, 2009; McLesky \& Waldron, 2004; Otis-Wilborn et al., 2005; Rice \& Zigmond, 2000; Rogers \& Babinski, 1999; Stayton \& McCollum, 2002).

Through planned, authentic efforts, school leaders correct misconceptions that collaboration is merely unstructured good communication (Friend, 2000). Teachers are guided to understand collaboration as a reciprocal relationship developed through "the prerogatives of questioning, answering, commenting or offering reflective observations on the dynamic [being] open to all participants" (Burbules \& Bruce, 2001, p. 1113; Kamens, 2007; Munby et al., 2001; Pugach \& Johnson, 2002; Shippen, Crites, Houchins, Ramsey, \& Simon, 2005; Van Larrhoven et al., 2006).

In an effective inclusive school, principals provide sufficient time for teachers to build critical collaborative skills of mutual trust and commitment to work together, self-reliance, interdependency, problem solving, confidence, and self-efficacy in teaching students of diverse cultural backgrounds and abilities (Cook, 2002; Golder et al., 2009; Griffin et al., 2009; Kamens, 2007; Lombardi \& Hunka, 2001; Mason \& Silva, 2001; McKenzie, 2009; Ross, Stafford, Church-Pupke, \& Bondy, 2006; Silverman, 2007; Stayton \& McCollum, 2002; Van Larrhoven et al., 2006). Teachers are given opportunities to develop and practise shared vision and goals regarding teaching and learning in inclusive classrooms (Griffin et al., 2009; Pugach \& Johnson, 2002). Designated professional development days are realigned for frequent teacher conversations about pedagogy, instructional differentiation, curriculum, and student progress as well as their own individual ongoing professional development needs.

In addition to developing partnerships between general and special education teachers, school principals need to support formation of collaborative relationships between schools and postsecondary teacher education institutions (Boyer \& Gillespie, 2000; Jenkins \& Ornelles, 2009). Teacher education programs need to be reconceptualised, as school leaders collaborate with teacher educators to integrate essential training in collaboration, interpersonal communication, problem solving, and understandings of diversity (Kamens, 2007; McKenzie, 2009; McLesky \& Waldron, 2004; Ross et al., 2006; Silverman, 2007; Stayton \& McCollum, 2002; Van Larrhoven et al., 2006). In an effective inclusive school, leaders collaborate with postsecondary educators to support teachers as action researchers who are continuously and critically examining the effectiveness of instruction for diverse student populations (Leko \& Brownell, 2009).

\section{Professional Development for Meaningful Teaching}

Finally, in establishing inclusive schools, principals support teachers in their quest for knowledge of "how to do it," (i.e., practical information about disabilities, diversity, and instruction; Gleeson \& Gunter, 2001, p. 110). Subsequently, pre-service special education teachers need meaningful and authentic inclusive experiences with students and their families (Forlin \& Hopewell, 2006; Golder et al., 2009). As well, practising teachers require ongoing professional development that reflects their current roles, addresses existing problems, and affords reflection on and deconstruction of their own previous pedagogical experiences (Golder et al., 2009; Ross 
\& Blanton, 2004). School leaders need to establish meaningful opportunities for ongoing professional development which actively engages teachers in acquiring knowledge and strategies in the context of the broader school reform movement (Leko \& Brownell, 2009). Consequently, the meaningful application of such new skills would then be more pragmatically linked to the realities of classrooms through authentic lesson plans, student assessment data, and curriculum samples (Ross \& Blanton, 2004; Leko \& Brownell, 2009; Desimone, Porter, Garet, Yoon, \& Birman, 2002; Golder et al., 2009; Jenkins \& Ornelles, 2009; Wedell, 2005). School leaders can thereby support teachers in acquiring a range of teaching strategies, as well as how to actually use different format resources to help meet the needs of all children (Brownell, Ross, Colon, \& McCallum, 2005; Golder et al., 2009; Jenkins \& Ornelles, 2009). Such a pragmatic focus on meaningful skill acquisition and use would have to be closely linked with pre-service teacher educators so as to supplement practical, enquiry-based coursework. The effective inclusive school would be an open environment that welcomes pre-service field experiences in a friendly, unsuspicious, and benign manner. Healthy attitudes, collaborative practice, and a culture of continuous learning and skill-acquisition would thereby be established. Classrooms would become more contextually situated within communities (Brownell et al., 2005; Lohrmann et al., 2006; McCutchen et al., 2002).

\section{Implications for School Administrators}

These six focus areas will guide school administrators in enhancing effective training for current teachers, inform initial training programs for new teachers, and enable teachers to also become leaders in implementing inclusion. The focus areas also speak to the many challenges and considerations experienced by school administrators in even attempting to develop and deliver ongoing professional development. While this brings clear implications for the broader field of school leadership, Stanovich and Jordan (1998) specifically named the school principal as being central to this process. They cited research which clearly establishes that it is the principals' attitudes, the norms they establish, and their own values and beliefs that imprint inclusive practices in the inclusive classroom.

In establishing and encouraging professional development for teachers, school administrators will also require professional development in helping teachers to maintain a balance in identifying their need for new training without compromising their professional identity or undermining their capabilities (Griffin et al., 2009). Likewise, Gleeson and Gunter (2001) noted the need for school leaders to achieve a similar balance in addressing the psychological impact of directing ongoing training for themselves as well as their staff.

School administrators require professional development that is practical, functional, and context-specific to their current roles and responsibilities (Powers, Rayner, \& Gunter, 2001). In striving to meet the professional training needs of individual teachers, professional development must help school leaders align the individual needs of teachers with ongoing school development plans and provincial standards and accountability mechanisms (Leko \& Brownell, 2009; Penuel, Fishma, Vamaguchi, \& Gallagher, 2007). School leaders must reconcile barriers and tensions inherent in the individual school context. Collaborative professional development for leaders is required to harmonize standards, organizational goals, individual learning needs of students (whether in mainstream or alternative programs), site-based performance management, and the need for intra- and inter-agency collaboration (Brownell et al., 2009; Leko \& Brownell, 2009; Powers et al., 2001; Watson, 2009). 


\section{Conclusion}

To support school administrators in enabling teachers to engage in shared leadership in response to globalization and inclusion, new models of professional development are required. These models must be informed by the wealth of knowledge indicating insufficiency of existing approaches in informing educators about meaningful and effective approaches to meeting the needs of diverse populations (Powers et al., 2001; Rayner \& Ribbins, 1998). Renewed postservice training for both administrators and teachers must be pragmatically linked with effective pre-service training. Such linkages will prioritize the acquisition and meaningful understanding of essential concepts including exceptionalities, cultural and linguistic differences, program planning, curriculum development, general and intensive instructional differentiation, assistive technology, social/emotional issues, collaborative practice, and self-efficacy (Angelle, 2009; DiPaola \& Walther-Thomas, 2003; Griffin et al., 2009; Leko \& Bownell, 2009).

The Canadian context illustrates the need for a renewal of professional development in education, one that faces the current challenges of expanded concepts of diversity, but which also supports school administrators in creating communities of learning that foster healthy attitudes as well as broader skill sets among their staffs. It is a need driven by pronounced demographic shifts, mushrooming cultural diversity, and an accepted paradigm of inclusion. Such is not only changing the fabric of our society but radically altering the realities of classrooms. Even a myopic glimpse at history affords the realization that training teachers for changes yet unpredicted is an impossible task. Existing knowledge identifies a need to respond now in order to support contemporary teachers in accommodating the needs of their current students. An informed first step in this process is a focus on training school administrators in developing and delivering meaningful and pragmatic training to their teachers. The effective, inclusive school, an educational environment increasingly identified as being essential in our society, is one where professional development is an ongoing, fluid balance between pre- and post-service training for both teachers and administrators.

\section{References}

Abosi, C. O. (2001). Thoughts on an action plan for the development of inclusive education in Africa. Retrieved April 15, 2007, from http://www.cec.sped.org/intl/natlover.html

Angelle, P. (2009). Confronting the unknown: Principal preparation training in issues related to special education. AASA Journal of Scholarship and Practice, 5(4), 5-9.

Baker, C., \& Martin, B. (2008). An examination of stakeholders' perceptions of the collaborative process utilized within a school-linked integrated partnership. Journal of School Public Relations, 29(1), $15-43$.

Baker, S., \& Smith, S. (2001). Linking school assessment to research-based practices in beginning reading: Improving programs and outcomes for students with and without disabilities. Teacher Education and Special Education, 24(4), 315-332.

Bakken, L., Clark, F. L., \& Thompson, J. (1998). Collaborative teaching: Many joys, some surprises and a few worms. College Teaching, 46(4), 154-157.

Banks, J., Cochran-Smith, M., Moll, L., Richert, A., Zeichner, K., LePage, P., et al. (2005). Teaching diverse learners. In L. Darling-Hammond \& J. Bransford (Eds.), Preparing teachers for a changing world (pp. 32-276). San Francisco: Jossey-Bass.

Billingsley, B. (2003). Special education teacher retention and attrition: A critical analysis of the literature. (COPSSE Document No. RS-2). Gainesville, FL: University of Florida, Center on Personnel Studies in Special Education. 
Boyer, L., \& Gillespie, P. (2000). Keeping the committed: The importance of induction and support programs for new special educators. Teaching Exceptional Children, 33(1), 10-15.

Brown, M. R., Higgins, K., Pierce, T., Hong, E., \& Thomas, C. (2004). Secondary students' perceptions of school life with regard to alienation: The effects of disability, gender and race. Learning Disability Quarterly, 26(4), 227-238.

Brownell, M. T., Adams, A., Sindelar, P., Waldron, N., \& Banhover, S. (2006). Learning from collaboration: The role of teacher qualities. Exceptional Children, 72(2), 169-185.

Brownell, M. T., Bishop, A. G., Gersten, R., Kungner, J., Dimino, J., \& Haager, D. (2009). The role of domain expertise in beginning special education teacher quality. Exceptional Children, 75(4), 391-411.

Brownell, M. T., Ross, D. D., Colon, E. P., \& McCallum, C. L. (2005). Critical features of special education teacher preparation: A comparison with exemplary practices in general teacher education. Journal of Special Education, 38(4), 242-252.

Buell, M., Hallam, R., Gamel-Mccormick, M., \& Scheer, S. (1999). A survey of general and special education teachers' perceptions and inservice needs concerning inclusion. International Journal of Disability, Development, and Education, 46(2), 143-156.

Burbules, N. D., \& Bruce, B. C. (2001). Theory and research on teaching as dialogue. In V. Richardson (Ed.), Handbook of research on teaching (pp. 1102-1121). Washington, DC: American Educational Research Association.

Buysse, V., Goldman, B. D., \& Skinner, M. L. (2003). Seeing effects on friendship formation among young children with and without disabilities. Exceptional Children, 68(4), 503-517.

Carlson, E., Chen, L., \& Schroll, K. (2002). SPeNSE: Study of personnel needs in special education. Final report of the paperwork substudy. Washington, DC: Special Education Programs (ED/OSERS).

Cochran-Smith, M., \& Lytle, S. L. (1999). Relationships of knowledge and practice: Teacher learning in communities. In A. Iran-Nejar \& P. D. Pearson (Eds.), Review of research in education (pp. 249305). Washington, DC: American Educational Research Association.

Cook, B. G. (2002). Inclusive attitudes, strengths, and weaknesses of pre-service general educators enrolled in a curriculum infusion teacher preparation program. Teacher Education and Special Education, 25(3), 262-277.

Cook, B. G., Tankersley, M., Cook, L., \& Landrum, T. (2001). Teachers' attitudes toward their included students with disabilities. Exceptional Children, 67(1), 115-135.

Crocker, R., \& Dibbon, D. (2008). Teacher education in Canada. Kelowna, BC: Society of the Advancement of Excellence in Education.

DiPaola, M. F., \& Walther-Thomas, C. (2003). Principals and special education: The critical role of school leaders. Retrieved February 4, 2009, from http://www.coe.ufl.edu.qe2a-proxy.mun.ca/copsse/pubfiles/IB-7.pdf.

Eggan, P. D., \& Kauchak, D. P. (2006). Strategies and models for teachers: Teaching content and thinking skills. Boston: Pearson/Allyn and Bacon.

Ellins, J., \& Porter, J. (2005). Departmental differences in attitudes to special educational needs in the secondary school. British Journal of Special Education, 32(4), 188-195.

Emanuelsson, I. (2001). Reactive versus proactive support coordinator roles: An international comparison. European Journal of Special Needs Education, 16(2), 133-142.

English Montreal School Board. (2010). Annual report 2008-2009. Retrieved February 2, 2010, from http://www.emsb.qc.ca/en/pressroom_en/pdf/Annual_Report0809_web_en.pdf

Fennick, E., \& Liddy, D. (2001). Responsibilities and preparation for collaborative teaching: Co-teachers' perspectives. Teacher Education and Special Education, 24(3), 229-240.

Forlin, C., \& Hopewell, T. (2006). Inclusion - the heart of the matter: Trainee teachers' perceptions of a parent's journey. British Journal of Special Education, 33(2), 55-61.

Foster, R. (2004). Leadership and secondary school improvement: Case studies of tensions and possibilities. International Journal of Leadership in Education, 8(1), 35-52. 
Friend, M. (2000). Perspective: Myths and misunderstandings about professional collaboration. Remedial and Special Education, 21(3), 130-132.

Fuchs, D., \& Fuchs, L. S. (1995). What's "special" about special education? Phi Delta Kappan, 76(7), $552-530$.

Gleeson, D., \& Gunter, H. M. (2001). The performing school and the modernization of teachers. In D. Gleeson \& C. Husbands (Eds.), The performing school: Managing teaching and learning in a performance culture. London: Routledge/Falmer.

Goddard, J. T., \& Hart, A. C. (2007). School leadership and equity: Canadian elements. School Leadership and Management, 27(1), 7-20.

Golder, G., Jones, N., \& Quinn, E. E. (2009). Strengthening the special educational needs element of initial teacher training and education. British Journal of Special Education, 36(4), 183-190.

Gould, W. T. S., \& Findlay, A. M. (1994). Population and the changing world order. New York: Wiley.

Government of Alberta. (2006). Alberta Commission on Learning. Retrieved April 10, 2008, from http://education.alberta.ca/department/ipr/commission.aspx

Government of Nova Scotia. (2007). Minister's review of services for students with special needs. Retrieved April 10, 2007, from http://www.ednet.ns.ca/events/special_education_review/documents/ review-committee-report-e.pdf

Griffin, C. C., Jitendra, A. K., \& League, M. B. (2009). Novice special educators' instructional practices, communication patterns, and content knowledge for teaching mathematics. Teacher Education and Special Education, 32(4), 319-336.

Hastie, P. A., Martin, E., \& Buchannan, A. M. (2006). Stepping out of the norm. An examination of praxis for culturally relevant pedagogy for African-American children. Journal of Curriculum Studies, 38(3), 293-306.

Hobbs, T., \& Westling, D. L. (2002). Mentoring for inclusion: A model class for special and general educators. Teacher Educator, 37(3), 186-201.

Hockenbury, J. C., Kauffman, J. M., \& Hallahan, D. P. (2000). What is right about special education. Exceptionality, 8(1), 3-11.

Hutchinson, N. L. (2009). Inclusion of exceptional learners in Canadian schools. Toronto, ON: Pearson Canada.

Jenkins, A., \& Ornelles, C. (2009). Determining professional development needs of general educators in teaching students with disabilities in Hawaii. Professional Development in Education, 35(4), 635-654.

Jordan, A., \& Stanovich, P. (2001). Patterns of teacher-student interaction in inclusive elementary classrooms and correlates with student self-concept. International Journal of Disability, Development and Education, 48(1), 33-52.

Kamens, M. W. (2007). Learning about co-teaching: A collaborative student teaching experience for preservice teachers. Teacher Education and Special Education, 30(3), 155-166.

Kamens, M. W., Loprete, S. J., \& Slostad, F. A. (2003). Inclusive classrooms: What practising teachers want to know. Action in Teacher Education, 25(1), 20-26.

Kauffman, J. M. (1981). Historical trends and contemporary issues in special education in the United States. In J. M. Kauffman \& D. P. Hallahan (Eds.), Handbook of special education (pp. 3-23). Englewood Cliffs, NJ: Prentice Hall.

Kauffman, J. M. (2000). The special education story: Obituary, accident report, conversion experience, reincarnation, or none of the above? Exceptionality, 8(1), 61-71.

Klinger, J. K., Vaughn, S., Schumm, J. S., Cohen, P., \& Forgan, J. W. (1998). Inclusion or pull-out: Which do students prefer? Journal of Learning Disabilities, 31(2), 148-158.

Laferriere, T., Erickson, G., \& Breuleux, A. (2007). Innovative models of web-supported universityschool partnerships. Canadian Journal of Education, 30(1), 211-238.

Leko, M. M., \& Brownell, M. T. (2009). Crafting quality professional development for special educators what school leaders should know. Teaching Exceptional Children, 42(1), 64-70. 
Levin, B. (2009). Initial teacher training is not that important: Commentary. Retrieved January 30, 2010, from http://educationalpolicy.org/publications/etw/canada/commentary/ etwcancom_091204.html

Levin, B., \& Fullan, B. (2008). Learning about system renewal. Educational Management, Administration, and Leadership, 36(2), 289-303.

Lipsky, D. K., \& Gartner, A. (1997). Inclusion and school reform. Baltimore: Paul H. Brookes.

Lloyd, C. (2008). Removing barriers to achievement: A strategy for inclusion or exclusion? International Journal of Inclusive Education, 12(2), 221-236.

Lohrmann, S., Boggs, E. M., \& Bambara, L. M. (2006). Elementary education teachers' beliefs about essential supports needed to successfully include students with developmental disabilities who engage in challenging behaviors. Research and Practice for Persons with Severe Disabilities, $31(2), 157-173$.

Lombardi, T. P., \& Hunka, N. J. (2001). Preparing general education teachers for inclusive classrooms: Assessing the process. Teacher Education and Special Education, 24(3), 183-197.

Loreman, T. (2007). Seven pillars of support for inclusive education. International Journal of Whole Schooling, 3(2), 22-38.

Loucks-Horsley, S., Love, N., Stiles, K., Mundry, S., \& Hewson, P. (2003). Designing professional development for teachers of science and mathematics. Thousand Oaks, CA: Corwin Press.

Lyon, G. R. (2005). Why scientific research must guide educational policy and instructional practices in learning disabilities. Learning Disability Quarterly, 28(2), 140-143.

Mason, T. C., \& Silva, D. Y. (2001). Beyond the methods course: Civics as the program core in elementary teacher education. In J. J. Patrick \& R. S. Leming (Eds.), Principles and practices of democracy in the education of social studies teachers (pp. 65-86). Bloomington, IN: ERIC Clearinghouse for Social Studies/Social Science Education.

Mastropieri, M. A., Scruggs, T. E., \& Graetz, J. (2005). Case studies in co-teaching in the content areas: Successes, failures and challenges. Intervention in School and Clinic, 40(5), 260-270.

McCarthy, C., Rezai-Rashti, G. M., \& Teasley, C. (2009). Race, diversity, and curriculum in the era of globalization. Oxford, UK: Wiley.

McCutchen, D., Abbott, R. D., Green, L. B., Beretvas, S. N., Cox, S., \& Potter, N. S. (2002). Beginning literacy: Links among teacher knowledge, teacher practice, and student learning. Journal of Learning Disabilities, 35(1), 69-86.

McKenzie, R. G. (2009). A national survey of pre-service preparation for collaboration. Teacher Education and Special Education, 32(4), 379-393.

McLesky, J., \& Waldron, N. L. (2004). Three conceptions of teacher learning: Exploring the relationship between knowledge and the practice of teaching. Teacher Education and Special Education, 27(1), 3-14.

Munby, H., Russell, T., \& Martin, A. K. (2001). Teachers' knowledge and how it develops. In V. Richardson (Ed.), Handbook of research on teaching (pp. 877-904). Washington, DC: American Educational Research Association.

Murphy, D. M. (1996). Implications of inclusion for general and special education. The Elementary School Journal, 96(5), 469-493.

National Commission on Educational Excellence. (1983). A nation at risk. Washington, DC: U.S. Government Printing Office.

Naylor, C. (2005, November). Inclusion in British Columbia's public schools: Always a journey, never a destination? Paper presented at the Canadian Teacher' Federation conference, Ottawa, ON. Retrieved February 13, 2010, from http://bctf.ca/diversity/reports/InclusionJourney/report.pdf

Norwich, B., \& Lewis, A. (2001). Mapping a pedagogy for special educational needs. British Educational Research Journal, 27(3), 313-329.

Ontario College of Teachers. (2006). Preparing teachers for tomorrow. Retrieved February 5, 2010, from http://www.oct.ca/teacher_education/tqr/default.aspx

Otis-Wilborn A., Winn, J., Griffin, C., \& Kilgore, K. (2005). Beginning special educators' forays into general education. Teacher Education and Special Education, 28(3-4), 143-152. 
Penuel, W. R., Fishma, B. J., Vamaguchi, R., \& Gallagher, L., P. (2007). What makes professional development effective? Strategies that foster curriculum implementation. American Educational Research Journal, 44(4), 921-958.

Philpott, D. F. (2007). Focusing on students: The final report of the ISSP/Pathways Commission. St. John's, NL: Queen's Printer:

Poulou, M. (2007). Personal teaching efficacy and its sources: Student teachers' perceptions. Educational Psychology, 27(2), 191-218.

Powers, S., Rayner, S., \& Gunter, H. (2001). Leadership in inclusive education: A professional development agenda for special education. British Journal of Special Education, 28(3), 108-112.

Pugach, M. C., \& Johnson, L. J. (2002). Collaborative practitioners, collaborative schools. Denver, CO: Love Publishing.

Rayner, S., \& Ribbins, P. (1998). Headteachers and leadership in special education. London: Cassell.

Rice, D., \& Zigmond, N. (2000). Co-teaching in secondary schools: Teacher reports of developments in Australian and American classrooms. Learning Disabilities Research and Practice, 15(4), 190197.

Richmond School Board. (2010). Annual report 2009. Retrieved February 5, 2009, from http://www.bced.gov.bc.ca/reports/pdfs/student_stats/038.pdf

Rogers, D. L., \& Babinski, L. (1999). Breaking through isolation with new teacher groups. Educational Leadership, 56(8), 38-40.

Ross, D. D., \& Blanton, L. (2004). Inquiry communities in special education teacher education. Teacher Education and Special Education, 27(1), 15-23.

Ross, D. D., Stafford, L., Church-Pupke, P., \& Bondy, E. (2006). Practicing collaboration: What we learn from a cohort that functions well. Teacher Education and Special Education, 29(1), 32-43.

Salend, S. J. (2001). Creating inclusive classrooms (4th ed.). Upper Saddle River, NJ: Merrill Prentice Hall.

Sands, D. S., Kozleski, E., \& French, N. (2001). Inclusive education for the $21^{\text {st }}$ century. Toronto, ON: Wadsworth/Thomson Learning.

Sassen, S. (1996). Losing control: Sovereignty in an age of globalization. New York: Columbia University Press.

Scruggs, T. E., Mastropieri, M. A., \& McDuffie, K. A. (2007). Co-teaching in inclusive classrooms: A metasynthesis of qualitative research. Exceptional Children, 73(4), 392-416.

Sharma, U., Forlin, C., Loreman, T., \& Earle, C. (2006). Pre-service teachers' attitudes, concerns and sentiments about inclusive education: An international comparison of novice pre-service teachers. International Journal of Special Education, 21(2), 80-93.

Shippen, M. E., Crites, S. A., Houchins, D. E., Ramsey, M. L., \& Simon, M. (2005). Preservice teachers' perceptions of including students with disabilities. Teacher Education and Special Education, 28(2), 92-99.

Silverman, J. C. (2007). Epistemological beliefs and attitudes towards inclusion in pre-service teachers. Teacher Education and Special Education, 30(1), 42-51.

Skrtic, T. M. (1995). The special education knowledge tradition: Crisis and opportunity. In E. L. Meyen \& T. M. Skrtic (Eds.), Special education and student disability: An introduction - traditional, emerging, and alternative perspectives. Denver, CO: Love Publishing.

Smith, J. D. (1998). Inclusion: Schools for all students. New York: Wadsworth Publishing.

Stainback, S., \& Stainback, W. (1992). Curriculum considerations in inclusive schools: Facilitating learning in inclusive classrooms. Toronto, ON: Paul H. Brookes Publishing.

Stanovich, P., \& Jordan, A. (1998). Canadian teachers' and principals' beliefs about inclusive education as predictors of effective teaching in heterogeneous classroom. The Elementary School Journal, 98(3), 221-238.

Stanovich, P. J., \& Jordan, A. (2000). Effective teaching as effective intervention. Learning Disabilities: A Multidisciplinary Journal, 10(4), 235-238. 
Stanovich, P. J., \& Jordan, A. (2002). Preparing general educators to teach in inclusive classrooms: Some food for thought. The Teacher Educator, 37(3), 173-185.

Statistics Canada. (2007). Portrait of the Canadian population 2006. Retrieved March 23, 2007, from www12.statcan.ca/english/census06/analysis/popdwell/highlights.cfm

Statistics Canada. (2008a). The daily. Retrieved April 9, 2008, from www12.statcan.ca/english/ 070426/d070426a.html.

Statistics Canada. (2008b). Ethnic diversity and immigration. Retrieved February 3, 2009, from www41.statcan.ca/2008/30000/ceb30000_000_e.htm

Stayton, V. C., \& McCollum, J. (2002). Unifying general and special education: What does the research tell us? Teacher Education and Special Education, 25(3), 211-218.

Taylor, L. S., \& Whittaker, C. R. (2009). Bridging multiple worlds: Case studies of diverse educational communities. Boston: Allyn and Bacon.

Thoma, C. A., Bartholomew, C. C., \& Scott, L. A. (2009). Universal design for transition: A roadmap for planning and instruction. Baltimore: Brookes Publishing.

Thomas, G. (1997). Inclusive schools for an inclusive society. British Journal of Special Education, 24(3), 103-107.

Thomas, G., \& Loxley, A. (2007). Deconstructing special education and constructing inclusion (2nd ed.). Retrieved May 10, 2010, from http://site.ebrary.com/lib/memorial/docDetail.action?docID=10229832

Toronto District School Board. (2009). Fact sheet. Retrieved November 4, 2009, from www.tdsb.on.ca

United Nations Development Programme. (2009). Overcoming barriers: Human mobility and development. Retrieved October 5, 2009, from http://www.undp.org/hdr2009.shtml

Van Larrhoven, T., Munk, D. D., Lynch, K., Wyland, S., Dorsch, N., Zurita, L., et al. (2006). Project ACCEPT: Preparing pre-service special and general educators for inclusive education. Teacher Education and Special Education, 29(4), 209-212.

Waldron, N. L., \& McLesky, J. (1998). The effects of an inclusive school program on students with mild and severe learning disabilities. Exceptional Children, 64(3), 395-405.

Watson, S. F. (2009). Barriers to inclusive education in Ireland: The case for pupils with a diagnosis of intellectual and/or pervasive developmental disabilities. British Journal of Learning Disabilities, $37(4), 277-284$.

Wedell, K. (2005). Dilemmas in the quest for inclusion. British Journal of Special Education, 32(1), 511.

Weinstein, C. S., Tomlinson-Clarke, S., \& Curran, M. (2004). Towards a conception of culturally responsive classroom management. Journal of Teacher Education, 55(1), 25-38.

Wiener, J. (2004). Do peer relationships foster behavioral adjustment in children with learning disabilities? Learning Disabilities Quarterly, 27(1), 21-30.

Wiener, J. (2009). Fostering social acceptance in inclusive classrooms. Education Canada, 49(4), 16-20.

Wiener, J., \& Tardif, C. (2004). Social and emotional functioning of children with learning disabilities: Does special education make a difference? Learning Disabilities Research and Practice, 19, 20 32.

Wilgosh, L., \& Scorgie, K. (2006). Fostering teacher understanding of parent issues when a child has a disability: A brief report. Developmental Disabilities Bulletin, 34, 127-136.

Zigmond, N., \& Baker, J. M. (1995). Concluding comments: Current and future practices in inclusive schooling. The Journal of Special Education, 29(2), 245-250.

\section{Authors' Note}

Correspondence concerning this article should be addressed to Dr. David Philpott, Box 117, GA Hickman Building, Faculty of Education, MUN, St. John's, NL, A1B 3X8.

Email: Philpott@mun.ca 